\title{
Kaidah dasar bioetika dalam pengambilan keputusan klinis yang etis
}

\author{
Dedi Afandi \\ KJF Kedokteran Forensik dan Medikolegal, Fakultas Kedokteran Universitas Riau
}

Korespondensi: Dedi Afandi, email: dediafandi4n6@gmail.com

\begin{abstract}
Abstrak
Kaidah dasar bioetika adalah suatu karakteristik yang unik dari prinsip yang dapat digunakan untuk menganalisis lebih tajam suatu standar, untuk membenarkan peraturan dan dapat menjadi pedoman dalam pengambilan keputusan klinis yang etis dalam praktik sehari-hari. Tinjauan pustaka ini bertujuan untuk memberi suatu metode dalam proses pengambilan keputusan klinis yang etis bagi dokter. Untuk manfaat kemajuan sains, tinjauan ini telah mengembangkan pemanfaatan kaidah dasar bioetika di bidang medis, terutama hubungan dokter-pasien, profesionalisme serta bioetika medis. Beberapa metode pengambilan keputusan klinis yang etis dibahas dan didiskusikan. Dengan meningkatkan pemahaman dan pelatihan penggunaan kaidah dasar bioetika dalam kehidupan seharihari diharapkan akan mampu menjaga hubungan dokter-pasien secara lebih baik.
\end{abstract}

Kata kunci: kaidah dasar bioetika; keputusan klinis; etika; hubungan dokter-pasien

\section{Abstract}

The basic moral principles are a unique characteristic of a principle that can be used to shapely analyze a standard, to justify rules and be a guide in ethical-clinical decision making in everyday practice. This literature review aims to provide a method of ethical clinical decision-making process for physicians. For the benefit of scientific advancement, this review has developed the utilization of the basic principles of bioethics in the medical field, especially the doctor-patient relationship, professionalism as well as medical bioethics. Several ethical methods of ethical-clinical decision-making are discussed. By improving the understanding and training of the basic moral principles in daily practice is expected to be able to maintain better doctor-patient relationships

Keywords: basic moral principle; clinical decision; ethics; doctor-patient relationship 


\section{PENDAHULUAN}

Dokter dalam menjalankan praktik seharihari sering kali menemukan isu etik yang terkadang dapat berkembang menjadi dilema etik. ${ }^{1,2}$ Seorang dokter senantiasa dihadapkan dalam penilaian moral untuk membuat suatu keputusan klinis yang etis. $^{3}$ Pada awal tahun 60-an, di saat kemajuan dalam bidang ilmu dan teknologi kedokteran berdampak pada hasil pengobatan dan kualitas hidup pasien yang lebih baik, ${ }^{4}$ praktik kedokteran di masyarakat berkembang dan berubah sejalan dengan keinginan dan kebutuhan masyarakat. Tulisan ini bertujuan untuk memberi cara atau metode dalam proses pengambilan keputusan klinis yang etis bagi dokter.

\section{METODE}

Penulisan artikel ini berdasarkan studi kepustakaan yang berhubungan dengan kaidah dasar bioetika dalam pengambilan keputusan klinis yang etis.

\section{HASIL DAN PEMBAHASAN}

\section{Etika dan Bioetika}

Kata etika secara etimologi berasal dari kata Yunani yaitu ethikos, ethos yang berarti adat, kebiasaan, praktik. ${ }^{5,6,7}$ Etika bukan suatu sumber tambahan bagi ajaran moral, melainkan merupakan filsafat atau pemikiran kritis dan mendasar tentang ajaran-ajaran dan pandangan-pandangan moral. Etika adalah suatu ilmu, bukan merupakan suatu ajaran. Pengertian lain tentang etika adalah ilmu tentang apa yang baik dan apa yang buruk dan tentang hak dan kewajiban moral (akhlak). ${ }^{8}$

Etika bersangkutan dengan manusia secara pribadi dalam "kemanusiannya", yaitu manusia yang sudah dan mampu menyadari dirinya sendiri dalam berpikir, bersikap, berbicara, bertingkah laku terhadap manusia lain dan (dalam) masyarakat, terhadap Tuhan sang Pencipta dan terhadap lingkungan tempat hidup beserta seluruh isinya. ${ }^{8}$ Etika, sebagaimana metode filsafat, mengandung permusyawaratan dan argumen eksplisit untuk membenarkan tindakan tertentu (etika praktis). Juga membahas asas-asas yang mengatur karakter manusia ideal atau kode etik profesi tertentu (etika normatif). Etika adalah pedoman berbuat sesuatu dengan alasan tertentu. Alasan tersebut sesuai dengan nilai tertentu dan pembenarannya. Etika penting karena masyarakat selalu berubah, sehingga kita harus dapat memilih dan menyadari kemajemukan (norma) yang ada (filsafat praksiologik). Jadi etika juga adalah alasan untuk memilih nilai yang benar di tengah belantara norma (filsafat moral). ${ }^{9}$

Etika adalah sebuah cabang filsafat yang berbicara mengenai nilai dan norma moral yang menentukan perilaku manusia dalam hidupnya. Etika sebagaimana metode filsafat, mengandung permusyawaratan dan argumen eksplisit untuk membenarkan tindakan tertentu (etika praktis), juga membahas asas-asas yang mengatur karakter manusia ideal atau kode etik profesi tertentu (etika normatif). 
Etika normatif (deontologi, teleologi, dan virtue) berbicara mengenai norma-norma yang menuntun tingkah laku manusia, serta memberi penilaian dan himbauan kepada manusia untuk bertindak sebagaimana seharusnya. ${ }^{9}$ Tujuan etika normatif ialah mencari prinsip-prinsip dasar yang memungkinkan kita menghadapi pandangan-pandangan normatif moral yang terdapat dalam masyarakat atau diperjuangkan oleh pelbagai ideologi secara rasional dan kritis. Kita seakan-akan mencari norma-norma dasar untuk menilai dengan kritis normanorma moral yang sudah beredar/ada.

Perilaku etis menyangkut perbuatan dalam kerangka baik dan benar. Analisis etis cenderung berpusat pada istilah-istilah ini sehingga melahirkan pandanganpandangan sebagai berikut: 7,9

1. Etika normatif dan metaetika. Etika normatif berarti sistem-sistem yang dimaksudkan untuk memberi petunjuk atau penuntun dalam mengambil keputusan yang menyangkut baik dan buruk, benar dan salah. Metaetika menganalisis logika perbuatan dalam kaitan dengan "baik" dan "buruk", "benar" dan "salah".

2. Bila kebaikan dipandang sebagai kunci tingkah laku etis, teori etika yang dihasilkan ditandai kepenuhan nilai. Yang benar (kebenaran) menjadi satu aspek kepenuhan nilai tersebut, yaitu seperangkat kewajiban kepada yang lain yang mesti dihormati dalam pencapaian kebaikan. Teori yang demikian disebut aksiologis (menekankan kiblatnya kepada tujuan akhir).

3. Bila kebenaran dianggap sebagai kunci perilaku etis, etika menjadi berkiblat kepada ide kewajiban dan tugas, berkisar pada pernyataan tentang prinsip-prinsip perilaku, dan bukan pada penelusuranpenelusuran konsekuensikonsekuensi. Teori-teori ini disebut deontologis (menekankan kewajiban), atau formalistis (menekankan prinsip).

4. Tetapi kebaikan maupun kebenaran dapat dilihat sebagai objektif (menggantikan sebuah faktor riil dalam hal-hal), atau subjektif (hanya mewakili proposal manusia). Maka lahirlah objektivisme etis atau subjektivisme etis.

Etika sangat erat kaitannya dengan moral. Bahkan secara etimologi moral mempunyai arti yang kurang lebih sama dengan etika, sekalipun bahasa asalnya berbeda. Namun yang membedakannya adalah bahwa moral merupakan nilai-nilai dan norma-norma yang menjadi pegangan bagi seseorang atau suatu kelompok dalam mengatur tingkah lakunya. Perbedaan etika dengan moralitas, bahwa moralitas adalah pandangan tentang kebaikan/kebenaran dalam masyarakat. Suatu hukum dasar masyarakat yang paling hakiki dan amat kuat. Juga suatu perbuatan benar atas dasar suatu prinsip 
(maxim). la merujuk pada perilaku yang sesuai dengan "kebiasaan atau perjanjian rakyat yang telah diterima", sesuai nilai dan pandangan hidup sejak masa kanakkanak, tanpa permusyawaratan. $5,7,9$

Etika dalam dunia kedokteran dikenal sebagai etika kedokteran. Etika kedokteran berfokus terutama dengan masalah yang muncul dalam praktik pengobatan., ${ }^{70,11}$ Dalam etika kedokteran isu-isu yang mengemuka terutama menyangkut tujuan pengobatan, refleksi kritis terhadap suatu tindakan dan mengembangkan otonomi dalam pengambilan keputusan dalam lingkup pasien, dokter dan pihak lain yang terkait dalam sistem praktik kedokteran. ${ }^{12}$ Sedangkan etika klinis lebih menyempit lagi ke lingkup klinis, yaitu suatu cabang praktis yang menyediakan suatu struktur pendekatan untuk mengidentifikasi, menganalisis dan memecahkan isu etik dalam praktik klinis. ${ }^{13}$

\section{Prinsip-Prinsip Bioetika}

Prinsip-prinsip bioetika pada dasarnya merupakan penerapan prinsip-prinsip etika dalam bidang kedokteran dan kesehatan. Etika kedokteran terapan, terbagi atas 2 kategori besar: (1) Principlism: mementingkan prinsip etik dalam bertindak. Termasuk dalam konteks ini adalah etika normatif, empat basic moral principle, konsep libertarianism (mengutamakan otonomi) serta beneficence in trust (berbuat baik dalam suasana kepercayaan). Dasar utama dalam principlism adalah bahwa memilih salah satu prinsip etik ketika akan mengambil keputusan, (2) Alternative principlism, termasuk dalam etika ini adalah etika komunitarian, etika naratif dan etika kasih sayang. ${ }^{11}$

Ada 3 teori etika normatif, yaitu:

1. Deontologi: asal kata deon (wajib), tidak bersyarat (kategoris) dan tidak bergantung pada tujuan tertentu. Benar tidaknya tindakan bergantung pada perbuatan/cara bertindak itu sendiri, bukan pada akibat tindakan. Dasar: kewajiban/keharusan, mutlak/absolut atau "kewajiban demi kewajiban". Kelemahan: pemicu fanatisme buta, tidak luwes dalam perkembangan zaman, tidak mampu memecahkan dilema etis. $^{13,14}$

2. Teleologi: bersyarat (hipotetis), benar tidaknya tindakan bergantung pada akibat-akibatnya. Bila akibat baik: wajib; bila buruk: haram. Hendak dicapai tujuan kedokteran tertentu namun tetap dalam bingkai "mempertahankan martabat kemanusiaan" (bukan tujuan asal-asalan). Dasar: pengalaman (efektif-efisien). Kelemahan: menghilangkan dasar pembawa kepastian etis, tidak berketetapan, pemicu "tujuan menghalalkan cara". 9,11

3. Virtue: keutamaan, benar tidaknya tindakan tergantung dari normanorma yang diambil. Dalam pengertian bahwa meminimalkan 
norma-norma kemanusiaan yang akan dikorbankan. Dasar: menghormati norma kebahagiaan manusia. Kelemahan: tidak mampu membuat keputusan klinis yang etik karena terlalu bersifat pribadi dan cenderung sangat individual.., 11

Beauchamp dan Childress (2001) menguraikan mengenai empat kaidah dasar (basic moral principle) dan beberapa rules di bawahnya. Keempat kaidah dasar tersebut adalah: ${ }^{14}$

1. Respect for Autonomy (menghormati autonomi pasien)

Otonomi secara literatur adalah aturan yang mengatur diri sendiri secara tenang dan tidak tergesa-gesa. Dasar-dasar respect for autonomy terkait erat dengan dasar mengenai rasa hormat terhadap martabat manusia dengan segala karakteristik yang dimilikinya karena ia adalah seorang manusia yang memiliki nilai dan berhak untuk meminta. Otonomi adalah aturan personal yang bebas dari campur tangan pihak lain. Beuchamp dan Childress merumuskan hal ini sebagai kata "tindakan otonomi tidak hanya ditujukan untuk mengontrol pembatasan oleh orang lain".

Respect for autonomy merupakan sesuatu yang hanya diwajibkan bila ia tidak bertentangan dengan prinsip-prinsip kaidah bioetika yang utama lainnya, contohnya: jika sebuah tindakan otonomi akan membahayakan manusia lain, maka prinsip respect for autonomy akan bertentangan dengan prinsip nonmaleficence, maka harus diputuskan prinsip yang ditetapkan.

\section{Beneficence (berbuat baik)}

Menurut teori Beuchamp dan Childress, prinsip atau kaidah ini tidak hanya menuntut manusia memperlakukan sesamanya sebagai makhluk yang otonom dan tidak menyakiti mereka, tetapi juga dituntut agar manusia tersebut dapat menilai kebaikan orang lain selanjutnya. Tindakan tersebut diatur dalam dasardasar beneficence. Bagaimanapun seperti yang telah disebutkan, dasar-dasar dari beneficence menuntut lebih banyak agent dibanding dengan dasar-dasar nonmaleficence. Beuchamp dan Childress menulis: "dalam bentuk yang umum, dasar-dasar beneficence mempunyai tujuan untuk membantu orang lain melebihi kepentingan dan minat mereka". Dasar dari beneficence mengandung dua elemen, yaitu keharusan secara aktif untuk kebaikan berikutnya, dan tuntutan untuk melihat berapa banyak aksi kebaikan berikutnya dan berapa banyak kekerasan yang terlibat.

3. Non-maleficence (tidak merugikan orang lain)

Tujuan prinsip ini adalah untuk melindungi seseorang yang tidak mampu (cacat) atau orang yang non-otonomi. Seperti yang telah dijelaskan, orang ini juga dilindungi oleh prinsip berbuat baik (beneficence). Jawaban etik yang benar adalah dengan melihat kebaikan lebih lanjut dari diri seseorang, tidak diperbolehkan untuk 
menyakiti orang lain. Prinsip ini mengemukakan bahwa keharusan untuk tidak melukai orang lain lebih kuat dibandingkan keharusan untuk berbuat baik.

\section{Justice (keadilan)}

Kesamaan merupakan inti dari justice, tetapi Aristoteles mengemukakan bahwa justice lebih daripada kesamaan, karena seseorang dapat merasa tidak diperlakukan secara semestinya walaupun telah diperlakukan sama satu dengan yang lain.

Teori filosofi mengenai keadilan biasanya menyangkut keutuhan hidup seseorang atau berlaku sepanjang umur, tidak berlaku sementara saja. Beuchamp dan Childress menyatakan bahwa teori ini sangat erat kaitannya dengan sikap adil seseorang pada orang lain, seperti memutuskan siapa yang membutuhkan pertolongan kesehatan terlebih dahulu dilihat dari derajat keparahan penyakitnya. Rawls merumuskan konsepsi khusus teori keadilan dalam bentuk dua prinsip keadilan yaitu: (1) setiap orang memiliki hak sama sejauh yang dapat dicakup keseluruhan sistem kesamaan kemerdekaan fundamental yang setara bagi kemerdekaan semua warga yang lain; (2) ketidaksamaan-ketidaksamaan sosial dan ekonomi ditata sedemikian sehingga keduanya: (a) paling menguntungkan bagi yang paling tertinggal, dan (b) melekat pada posisi-posisi dan jabatan-jabatan terbuka bagi semua di bawah syarat kesamaan kesempatan yang fair. ${ }^{15,16}$

\section{Etika Klinis}

Dalam dunia kedokteran, fondasi moral hubungan dokter pasien adalah inti etika kedokteran. Pembahasan dalam etika kedokteran lebih dititikberatkan pada fondasi moral yang mengatur hubungan dokter pasien. Konsep hubungan ini akan lebih mempertajam keputusan-keputusan klinis yang akan dibuat oleh dokter dalam berbagai situasi, sehingga akan tersusun standar perilaku profesional. ${ }^{14}$ Fondasi etika kedokteran tersebut dapat dilihat dari gambar 1.

\section{Pengambilan Keputusan Klinis Yang Etis}

Etika klinis merupakan suatu metodologi dalam proses pengambilan keputusan klinis yang etik. Beberapa contoh metodologi tersebut adalah:

- Casuistry: metodologi pengambilan keputusan etik adalah menganalogikan situasi dan kondisi suatu kasus terhadap kasus terdahulu yang sudah ada pemecahan masalahnya secara konsensus. Kelemahan metode ini adalah bahwa tidak ada konsensus yang abadi.

- Moral Pluralism: dikembangkan oleh Jonsen, Siegler and Winslade yang membagi 4 jenis kategori yang memerlukan analisis moral, sebagaimana yang dapat dilihat pada gambar 2 . 


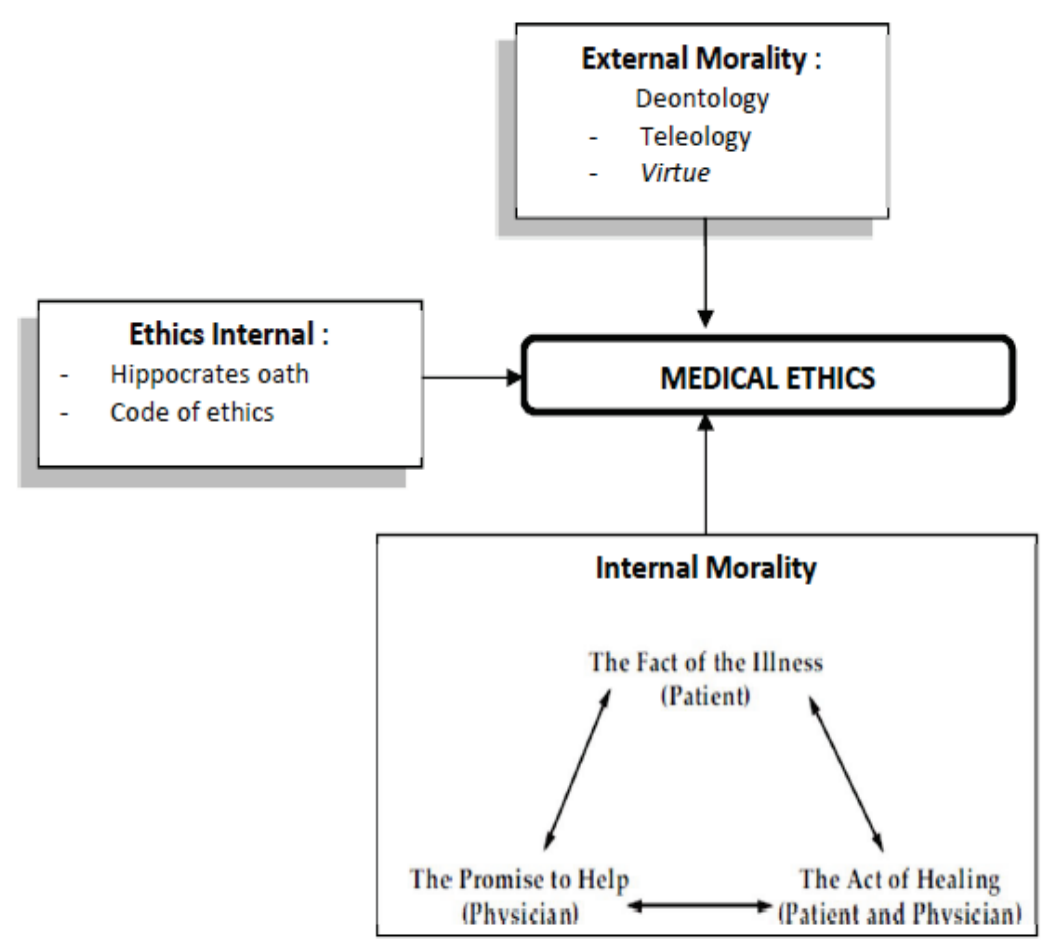

Gambar 1. Fondasi etika kedokteran ${ }^{17}$

Langkah yang dilakukan adalah mengkontekstualitas-kan masalah-masalah yang ada ke dalam masing-masing kategori. Untuk selanjutnya dilakukan pertimbangan keputusan apa yang akan diambil bila ada dua kategori yang berseberangan. Sebagai catatan bahwa 4 kategori yang ada hanya merupakan alat bantu untuk meninjau ulang kasus dan bukan ditujukan sebagai prioritas etik. Keputusan tetap harus diambil dari pertimbangan ke empat kategori tersebut. ${ }^{11,12}$ Kekurangan metode ini adalah bahwa tidak ada analisis kritik terhadap hasil keputusan yang telah kita ambil. ${ }^{11}$

Ketika seorang pasien datang ke seorang dokter, pertanyaan yang pertama kali muncul di benak sang dokter adalah apa yang akan saya lakukan? Dan banyak pertanyaan lain yang akan muncul dalam benak si dokter. Semua pertanyaanpertanyaan tersebut dapat direduksi menjadi tiga pertanyaan yaitu:

1. Apa yang dapat menjadi salah? Ini adalah pertanyaan yang menyangkut diagnostik dan klasifikasi masalah. Dalam hal ini dokter akan menggunakan segenap kemampuan medis yang dimilikinya untuk dapat meminimalisir kesalahan diagnosis yang akan dibuat.

2. Apa yang dapat dilakukan? Ini adalah pertanyaan selanjutnya yang menyangkut terapi terhadap pasien bila diagnosis atau penyakit pasien sudah dapat ditegakkan. Dokter akan 
mempertimbangkan

segala

kemampuannya untuk memberikan yang terbaik bagi pasien.

3. Apa yang seharusnya dilakukan pada pasien ini? Saat diagnosis sudah dapat ditegakkan dan pilihan terapi sudah diputuskan berdasarkan keilmuan, pertanyaan kemudian yang akan timbul adalah, haruskah terapi yang sudah dipilih diberikan pada pasien ini? Kalau memang benar, apakah sudah tepat dan sesuai dengan keadaan dan kondisi pasien? Atau apakah pasien menyetujui pilihan terapi yang kita berikan?

\begin{tabular}{|c|c|}
\hline $\begin{array}{l}\text { MEDICAL INDICATION } \\
\text { 1. What is patient's medical problem? } \\
\text { history? diagnosis? prognosis? } \\
\text { 2. Is problem acute? chronic? critical? } \\
\text { emergent? reversible? } \\
\text { 3. What are goals of tretment? } \\
\text { 4. What are probabilities of success? } \\
\text { 5. What are plans in case of therapeutic } \\
\text { failure? } \\
\text { 6. In sum, how can this patienr be } \\
\text { benefited by medical and nursing care, } \\
\text { and how can harm be avoided? }\end{array}$ & $\begin{array}{l}\text { PATIENT PREFERENCES } \\
\text { 1. What has the patient expressed about } \\
\text { preferences for treatment? } \\
\text { 2. Has patient been informed of benefits and } \\
\text { risks, understood, and given consent? } \\
\text { 3. Is patient mentally capable and legally } \\
\text { competent? what is evidence of } \\
\text { incapacity? } \\
\text { 4. Has patient expressed prior preferences } \\
\text { (eg. Advance directives)? } \\
\text { 5. If incapacitated, who is appropriate } \\
\text { surrogate? Is surrogate using appropriate } \\
\text { standards? } \\
\text { 6. Is patient unwilling or unable to cooperate } \\
\text { with medical treatment? If so, why? } \\
\text { 7. In sum, is patient right to choose being } \\
\text { respected to extent possible in ethics and } \\
\text { law? }\end{array}$ \\
\hline $\begin{array}{l}\text { QUALITY OF LIFE } \\
\text { 1. What are the prospect, with or without } \\
\text { treatment, for a return to patient's normal } \\
\text { life? } \\
\text { 2. Are there blases that might prejudice } \\
\text { provider's evaluation of patient's quality } \\
\text { of life? } \\
\text { 3. What physical, mental, and social deficits } \\
\text { is patient likely to experience if tretment } \\
\text { succeeds? } \\
\text { 4. Is patient's present or future condition } \\
\text { such that continued life might be judge } \\
\text { undesirable by [him/her]? } \\
\text { 5. Any plan and rationale to forgo treatment? } \\
\text { 6. What plans for comfort and palliative care? }\end{array}$ & $\begin{array}{l}\text { CONTEXTUAL FEATURE } \\
\text { 1. Are there family issues that might } \\
\text { influence treatment decisions? } \\
\text { 2. Are there provider (physicians and nurses) } \\
\text { issues that might influence treatment } \\
\text { decicions? } \\
\text { 3. Are there financial and economic factors? } \\
\text { 4. Are there religious, cultural factors? } \\
\text { 5. Is there any justification to breach } \\
\text { confidentiality? } \\
\text { 6. Are there problems of allocation of } \\
\text { resources? } \\
\text { 7. What are legal implications of treatment } \\
\text { decisions? } \\
\text { 8. Is clinical research or teaching involved? } \\
\text { 9. Any provider or institutional conflict of } \\
\text { interest? }\end{array}$ \\
\hline
\end{tabular}

Gambar 2. Empat dimensi analisis etika klinis ${ }^{13}$

Dalam situasi konkret mungkin pertanyaan

1 dan 2 akan relatif lebih mudah diatasi oleh dokter, akan tetapi bisa juga pertanyaan nomor 3 akan membuat jawaban dari pertanyaan nomor 2
berubah.

Bagaimana jika dalam langkah-langkah pertanyaan tersebut menimbulkan dilema 
bagi dokter untuk mengambil keputusan? Ada empat pendekatan yang dapat digunakan untuk dapat memecahkan dilema tersebut, yaitu: ${ }^{20}$

- Single-Principle

Theories, prinsipnya di sini adalah memilih satu prinsip dengan mengalahkan prinsip-prinsip yang lain setelah melalui pertimbangan yang matang.

- Ranking (Lexically Ordering) Principles, prinsipnya di sini adalah kita membuat ranking (leksikal) dari prinsip-prinsip yang ada dan keputusan diambil pada prinsip yang urutannya terletak paling atas.

- Balancing, prinsipnya adalah keputusan diambil dengan menyeimbangkan prinsip-prinsip yang ada.

- Combining ranking and balancing, prinsipnya di sini adalah kita berusaha me-ranking dan sedapat mungkin membuatnya prinsipprinsip tersebut dalam satu kelompokan. Akan tetapi pada praktiknya sangat sulit, karena banyaknya nilai yang satu sama lain saling mengalahkan dan tidak dapat diseimbangkan.

Purwadianto $^{19}$ mencoba untuk menerapkan konsep prima facie melalui pendekatan empat basic moral principle. Dalam konteks beneficence, prinsip prima facie-nya adalah sesuatu yang (berubah menjadi atau dalam keadaan) yang umum.
Artinya ketika kondisi pasien merupakan kondisi yang wajar dan berlaku pada banyak pasien lainnya, sehingga dokter akan melakukan yang terbaik untuk kepentingan pasien. Juga dalam hal ini dokter telah melakukan kalkulasi di mana kebaikan yang akan dialami pasiennya akan lebih banyak dibandingkan dengan kerugiannya. Dalam konteks nonmaleficence, prinsip prima facie-nya adalah ketika pasien (berubah menjadi atau dalam keadaan) gawat darurat yang memerlukan suatu intervensi medik dalam rangka penyelamatan nyawanya. Dapat pula dalam konteks ketika menghadapi pasien yang rentan, mudah dimarjinalisasikan dan berasal dari kelompok anak-anak atau orang uzur ataupun juga kelompok perempuan (dalam konteks isu jender). Dalam konteks otonomi, nampak prima facie di sini muncul (berubah menjadi atau dalam keadaan) pada sosok pasien yang berpendidikan, pencari nafkah, dewasa dan berkepribadian matang. Sementara justice nampak prima facie-nya pada (berubah menjadi atau dalam keadaan) konteks membahas hak orang lain selain diri pasien itu sendiri. Hak orang lain ini khususnya mereka yang sama atau setara dalam mengalami gangguan kesehatan. di luar diri pasien, serta membahas hak-hak sosial masyarakat atau komunitas sekitar pasien. ${ }^{19}$

Dalam kesehariannya seorang dokter senantiasa dihadapkan dalam penilaian moral untuk membuat suatu keputusan klinis yang etis. Istilah penilaian moral 
dapat didefinisikan menjadi 4 hal yang berbeda. Pertama, kegiatan berpikir apakah nilai moral objek yang memberi (dapat berupa tindakan, personal, institusi atau keadaan) mempunyai sifat moral secara khusus, dapat berupa yang umum (seperti: kebenaran, kejahatan) atau yang spesifik (tidak peka, integritas). Kedua, keadaan yang tercipta dari pandangan bahwa objek tersebut memiliki sifat moral. Ketiga, bahwa ada makna dari keadaan tersebut: apa yang kita pandang, dari pada apa pandangan kita. Dan yang keempat, istilah tersebut dapat dibaca sebagai penghargaan atau pujian, mengarah kepada moral yang baik yang juga biasa disebut "ketajaman moral" atau "kebijaksanaan moral". ${ }^{21}$

\section{KESIMPULAN}

Penggunaan kaidah dasar bioetika merupakan salah satu metode yang dapat digunakan dalam pengambilan keputusan klinis yang etis. Konsep prima facie akan memudahkan bagi dokter dalam membuat keputusan medis yang etis dalam kehidupan sehari. Dengan meningkatkan pemahaman dan pelatihan penggunaan kaidah dasar bioetika dalam kehidupan sehari-hari diharapkan akan mampu menjaga hubungan dokter secara lebih baik.

\section{DAFTAR PUSTAKA}

1. Wasisto B, Suganda S. Perilaku profesional sebagai kontinum etis, disiplin dan hukum dalam mencegah masyarakat gemar menggugat (litigious society). Proceeding Pertemuan Nasional IV Jaringan Bioetika dan Humaniora Kesehatan Indonesia (JBHKI). Jakarta: Fakultas Kedokteran Universitas Indonesia, 30 November - 2 Desember 2004.

2. Mayeda M, Takase K. Need for enforcement of ethicolegal education - an analysis of the survey of postgraduate clinical trainers. BMC Medical Ethics. 2005; 6:8. Diunduh tanggal 4 Juli 2014 dari http://www.biomedcentral.com/content/pdf/1472-6939-6-8.pdf.

3. Craig E. Moral Judgment. The Routledge of philosophy. London: Routledge; 1998.

4. Nambiar RM. Professional development in changing world. Singapore Med J. 2004; 45(12): 5517.

5. Bertens K. Etika. Jakarta: Gramedia Pustaka Utama; 2005. p 279-83.

6. Jacobalis S. Perkembangan ilmu kedokteran, etika medis dan bioetika. Jakarta: Sagung Seto; 2005.

7. Bagus L. Kamus filsafat. Jakarta: Gramedia Pustaka Utama; 2005.

8. Purwadianto A. Kaidah dasar moral dan teori etika dalam membingkai tanggung jawab profesi kedokteran. Makalah penyegaran etika kedokteran. Jakarta : FKUI, 18 Februari 2003.

9. Darmadipura MS. Dari etik ke bioetik. Dalam: Darmadipura MS (editor). Kajian bioetik. Surabaya: Airlangga University Press; 2005. p.25-33. 
10. Thomasma DC. Chapter 2: Theories of medical ethics: the philosophical structure in Military medical ethics volume 1, Lounsbury DE (ed). Washington: Walter Reed Army Medical Center; 2003.p 23-59.

11. Jonsen AR, Siegler M, Winslade WJ. Clinical ethics: a practical approach to ethical decisions in clinical medicine 5th ed. USA: McGraw-Hill; 2002.

12. Williams JR. Medial ethics manual. France: WMA; 2005.

13. Pellegrino ED, Thomasma DC. The virtue in medical practice. New York: Oxford University Press; 1993.

14. Beuchamp TL, Childress JF. The principle of biomedical ethics, ed 3rd. New York: Oxford University Press; 2001.

15. Lubis AY. Dekonstruksi epistemologi modern; dari posmodernisme, teori kritis, poskolonialisme hingga cultural studies. Jakarta: Pustaka Indonesia Satu; 2006.p54-66.

16. Rasuanto B. Keadilan sosial; pandangan deontologis Rawls dan Habermas. Jakarta: Gramedia Pustaka Utama; 2005: 97-180.

17. Pellegrino ED. Chapter 1: The moral foundation of the patient-physician relationships: the essence of medical ethics in Military medical ethics volume 1, Lounsbury DE (ed). Washington: Walter Reed Army Medical Center; 2003.p1-22.

18. Murray EM, Lo B, Pollack L, Donelan K, Lee K. Direct-to-consumer advertising: physicians' view of its efeect on quality of care and the doctor-patient relationships. J Am Board Fam Pract. 2003; 16: 513-24.

19. Purwadianto A. Segi kontekstual pemilihan prima facie kasus dilemma etik dan penyelesaian kasus konkrit etik. Proceeding ilmiah Pertemuan Nasional III JBHKI, FKUI, Jakarta, 30 November - 2 Desember 2004.

20. Veatch RM. The principle of autonomy and the doctrine of informed consent in: The basics of bioethics. New Jersey: Prentice-Hall, Inc; 2000.

21. Craig E. Moral Judgment. The Routledge of philosophy. London: Routledge; 1998. 